\title{
A matter of entrepreneurial decisions: Dairibord Holdings Limited (DHL) in Zimbabwe
}

\begin{abstract}
Synopsis: The case study focussed on the dairy sector in the southern African country of Zimbabwe. It offered an analysis of the management and business development approaches DHL employed in the country's dairy sector. The narrative detailed how DHL's commercial performance progressively declined overtime. Several factors including; operational inefficiencies, intensive competition, political, socio-economic issues, and natural disasters were attributable to its decline. To mitigate DHL's business development challenges, Antony and his top management's reprised "restructure, expand and diversify" strategy only achieved inconsistent commercial results. The scale and size of these results unequivocally necessitated radical entrepreneurial methods to turnaround its fortunes. It was indeed a matter of entrepreneurial decisions!
\end{abstract}

Methodology: The case study utilized secondary analysis as its main strategy for generating relevant data. The rationale for adopting the principles of secondary analysis was to take advantage of quality archived data, public and readily available information concerning DHL's commercial performance. Setting up to undertake secondary analysis for the purpose of DHL's narrative was less-expensive, and it was less time consuming when compared to structured interviews and selfadministered questionnaires. Hence, it was deemed appropriate for producing a narrative on a company whose archived financial reports and publicly available research information were accessible.

Relevant course levels: DHL's narrative is relevant for students studying entrepreneurship, business management and international business at postgraduate and undergraduate levels.

Theoretical basis: The multi-dimensional constructs of entrepreneurship and strategic management provided the theoretical basis for constructing a narrative about DHL's business activities in Zimbabwe's dairy sector. Particularly, the entrepreneurial decision-making paradigm offered some insight, direction and guidance in analysing the strategies Antony and his top management team applied in their planning and management at DHL. Equally, strategic management theories provided useful instructions for exploring business development issues in a rapidly changing business terrain that was presented by the dairy sector in Zimbabwe.

Keywords: entrepreneurship, strategic entrepreneurship, strategic management, entrepreneurial decision-making, entrepreneurial leadership, dairy market, Zimbabwe, southern Africa 


\section{Introduction}

Against the backdrop of inconsistent commercial performances at DHL, its board of directors set out to change the fortunes of the dairy milk and milk beverages enterprise. With Mr Antony Mandiwanza an MBA graduate and its chief executive officer, the top management team at DHL initiated a deliberate "restructure, expand and diversify" strategy. The ultimate goal was to enhance efficiency through cost-cutting exercises and to boost sales in order to stabilise fluctuating revenues and operating profit margins (see table 1). This was anticipated to kick start the turnaround DHL desperately needed.

An alarming slump in revenues was recorded between 2013 and 2014 highlighting a significant $11 \%$ dip. That is, from a $\$ 100 \mathrm{~m}$ income in 2013 to $\$ 43.8 \mathrm{~m}$ in 2014 (INVESCI, 2014). Moreover, for 2013 and 2014 trading periods operating profits margins were negative as illustrated in Table 1. This was perhaps a strong signal that drastic decisions to turnaround DHL would be justifiable.

Table 1: DHL's performance between 2009 to 2014

\begin{tabular}{|l|r|r|r|r|r|r|}
\hline Profit \& Loss (\$000) & 2009 & 2010 & 2011 & 2012 & 2013 & 2014 \\
\hline Revenue & 43,425 & 75,187 & 95,983 & 106,889 & 100,052 & 43,792 \\
\hline Gross Margin & 13,894 & 23,888 & 31,141 & 32,467 & 24,197 & 43,792 \\
\hline Operating Profit & $\mathbf{4 , 6 3 8}$ & $\mathbf{8 , 6 2 2}$ & $\mathbf{1 0 , 8 4 6}$ & $\mathbf{9 , 8 0 0}$ & $\mathbf{( 1 , 8 3 8 )}$ & $\mathbf{( 6 2 7 )}$ \\
\hline Net Finance Costs & $\mathbf{( 5 5 0 )}$ & $\mathbf{( 6 0 5 )}$ & $\mathbf{( 8 7 9 )}$ & $\mathbf{( 3 7 9 )}$ & $\mathbf{( 4 7 9 )}$ & $(\mathbf{2 5 7 )}$ \\
\hline Pre-tax profit from continuing operations & 4,089 & 8,017 & 9,967 & 9,421 & $(2,317)$ & $(\mathbf{8 8 4})$ \\
\hline Tax (expense)/ credit & $(\mathbf{9 1 5 )}$ & $(1,876)$ & $(2,780)$ & $(2,234)$ & 536 & 404 \\
\hline
\end{tabular}


In response to inconsistent commercial performances, DHL's recovery plan was rolled out again in 2015, on top of the corporate adjustments that had started way back in 2000. The top management team rationalised some of DHL's production facilities, and even closed a lessefficient milk processing station in Gweru. Equally, the team had invested $\$ 5.4 \mathrm{~m}$ on average per year for a period of approximately 4 years, between 2010 and 2014, using returned profits and bank loans. Utilising such investment methods, the team acquired strategic business units (SBUs) that included; Lyons, and M. E. Charhons, and established NFB Logistics, while it introduced a new beverage namely: Pfuko yeMaheu -a traditional favourite. Furthermore, the team commissioned new facilities for nutriplus and yoghurt production and processing to boast falling revenues (Jaravaza et al., 2014; DHL, 2017).

Notwithstanding Antony and his team's seemingly entrepreneurial decision making, there were other factors that were at play. For example, a research report produced by INVESCI for DHL concluded that, consumer spending on Dairibord's milk and milk beverages had gone down, when compared to cheaper foreign dairy products imported from South Africa (SA) (INVESCI, 2014; The Zimbabwe Independent, 2016). This reported change in consumer spending habits coincided with a depreciated Malawi currency (the 'kwacha') in 2013 (DHL, 2017). Because DHL had a 40\% stake in Dairibord Malawi Limited (DML), a depreciated kwacha meant its revenues as a group were in some way affected. Clearly, the new developments in Malawi contributed to the problems DHL had in its domestic markets. This all happened at the back of fresh farm invasions of 2009, a decade after the first wave in 1999 (Zvomuya, 2009). Both the 1999 and 2009 farm invasions played a part in disrupting the milk supply-chain which comprised established farmers who regularly supplied DHL with millions of litres of milk. 
Moreover, the general political and the socio-economic conditions in Zimbabwe which were in a bad shape, and had been in such a state for a long time, further complicated an already fragile business environment for DHL. The advent of small scale milk producing farmers in the dairy market following the ill-conceived 2008 indigenisation policy (Financial Times (FT), 2013; Marazanye, 2016), also exacerbated DHL's desperate situation (Chamboko and Mwakiwa, 2016; Hanyani-Mlambo, 2000; Hanyani-Mlambo et al., 1998; Mupunga, 1994).

In its export markets that included; Zambia, Botswana, Malawi, Mozambique and South Africa, business largely remained uncertain due to deteriorated multi-lateral relations with former President Robert Mugabe's administration. The Rand fluctuations in SA did not help either. A devalued Rand meant that imported milk and milk beverages from SA, were cheaper for consumers in Zimbabwe. As of 2017, it still remained unclear whether Antony and his team's decisions concerning revitalising DHL had paid off.

\section{DHL's History Timeline}

Dairibord Holdings Limited was formally called Dairibord Zimbabwe Limited (DZL) -an outcome of its conversion from its original name Dairy Marketing Board (DBM). Established in 1953 as a state-owned-enterprise (SOE), DMB received all milk supplied by registered producers which it then processed and distributed to consumers at prescribed prices (Reserve Bank of Zimbabwe (RBZ), 2007). During its early years of establishment, Dairy Marketing Board was the only dairy company in the then colonial Rhodesia. When it was privatised in 1994, 14 years after Zimbabwe gained independence from the colonial rule, DMB had all the characteristics of an inefficiently managed SOE. The enterprise had incurred huge operational deficits due to controlled milk prices which were not timely reviewed (RBZ, 2007). Employee conditions of service were poor which resulted in low staff morale and low retention rates. 
This, on top of the other problems the SOE had encountered, rendered it unsustainable in the long-term. Natural causes also exerted operations management related pressures on the enterprise. Especially, the drought experienced in the early 90s in Zimbabwe which led to increased costs of stock feeds and it meant that farmers' milk yields were significantly reduced, notwithstanding increased producer prices (Makamure, 2001; Muir-Leresche and Muchopa, 2007).

On the basis of the combined effects of the problems on DMB's business activities highlighted above, it was finally declared one of the several loss-making SOEs by the Zimbabwean government, because its financial budget requirements were no longer cost-effective. Between 1978 and 1990, DMB's operational deficit grew from $Z \$ 2$ million to a staggering $Z \$ 60$ million (RBZ, 2007). Consequently, the government which was the only stakeholder in the dairy company and had full control, at the time, (Binns and Winslow, 1997) realised that it could no longer afford such huge losses. The government wasted no time in commercialising the company in 1991 under its controversial Economic Structural Adjustment Program (ESAP) (Marazanye, 2016; Masunungure and Zhou 2006). Accordingly, a board of directors was appointed to oversee its operations (Binns and Winslow, 1997). The new board took charge of the enterprise from 1991 to 1994 , and during this period $\mathrm{DMB}$ was turned around from a company with a $\mathrm{Z} \$ 60 \mathrm{~m}$ deficit to a profitable enterprise.

Its turnaround was perhaps down to several business restructuring decisions -a strategy that had become a tradition at DMB. Consistent with its restructuring strategy staff numbers at the dairy company were reduced, less-commercially viable depots in the urban and rural areas were leased, milk roundsmen services were privatised, its transport fleet was upgraded, tighter budget controls were implemented, and milk prices were increased (Muir-Leresche and Muchopa, 2007). Thus, the significant losses previously experienced at the enterprise were transformed into profits within a year. 
This was not only down to operational efficiencies, but also increased consumer prices for commodities often considered in economic terms relatively price inelastic. Plus, at the time this was happening DMB had limited or no competition; it basically had the market monopoly (Binns and Winslow, 1997). Within a period of three years, that is between 1991 and 1994 of being commercialised, the government gained confidence in the abilities of the new board of elected directors as they had succeeded in turning around DMB's fortunes (Binns and Winslow, 1997). As such, DMB was fully privatised, and was thereafter registered as Dairibord Zimbabwe Limited in July 1994 under the Companies' Act. The government still retained 100\% equity and had full control of the enterprise. For continuity, the government reinstated the same directors who were further tasked with leading the company through to privatisation (Binns and Winslow, 1997; DHL, 2017; RBZ, 2007).

DZL soon established itself as a well-controlled and transparent enterprise in Zimbabwe. During the 1994 to 1997 period the company gained public confidence, and by September of 1997 it was successfully listed on the Stock Exchange (ZSE) in Zimbabwe (Binns and Winslow, 1997). It became the first SOE to be fully privatized in the country (Godana and Hlatshwayo, 1998; MuirLeresche and Muchopa, 2006; RBZ, 2007). As a show of public confidence in the organization and the privatisation process, the counter was oversubscribed (Binns and Winslow, 1997). Thus, DZL began its existence as a debt-free, and a profitable enterprise that had a positive cash flow (Godana and Hlatshwayo, 1998).

However, a further round of organisational restructuring was initiated in 2005. This triggered another change of its name. As previously mentioned, this was a procedure the enterprise had become accustomed to. This time, DZL was converted into a holding company - Dairibord Holdings Limited. The rationale for this move was to create stand-alone subsidiaries which were considered a 'strategic fit' to the dairy company's corporate venturing approach (DHL, 2017). 
In the light of intractable challenges that the company had endured over the years, creating standalone business units was a deliberate attempt to realign DHL's business development activities and get the company back onto the front foot. Getting back to a market leadership position was undoubtedly a priority for DHL, given that the dairy market in Zimbabwe had shown a tendency to change rapidly with limited warnings.

\section{Business Development Decisions at DHL}

When the government finally offloaded its shares in 1998, DZL's top management team that included; professional staff, senior management and regionally-based general managers with Antony as the chief executive officer, took full control. The top management team continued to broaden DZL's product range and business development activities (DHL, 2017). In 2001, DHL took full ownership of Lyons and this was followed by a $40 \%$ stake in M. E. Charhons -a confectionary company in Zimbabwe (DHL, 2017). To complement its corporate venturing DHL established a new transport and logistics company - NFB Logistics in 2003. Further investments in new processing facilities for ice cream, cascade, nutriplus and yoghurt followed in the same year.

In 2005 Antony and his team were at it again. As previously explained, they converted DZL into a holding limited company with stand-alone subsidiaries, and in 2006 the company's name was swiftly changed to Dairibord Holdings Limited. As from 2012 a 'botchpotch' of business decisions followed. To start with, the top management team offloaded DHL's 40\% equity in M. E. Charhons to Cairns Holdings in 2012. In the same year, DHL disposed its own canning company - Mulanje Peak Foods. By 2013, DHL had commenced what Antony described as its 'rationalisation process'. 
DHL's 'rationalisation process' led to the relocation of some of its factories and operations from Mutare and Bulawayo to the capital city -Harare and a nearby town of Chitungwiza. In 2015, DHL opened a sterilised milk facility in Chipinge -a city to the south east of Zimbabwe, and it simultaneously introduced a new traditional beverage it branded Pfuko yeMaheu which was processed at its Chitungwiza factory (DHL, 2017; The Source, 2017). As the team introduced its new beverage (Pfuko yeMaheu), it did so while scaling down production at its other major facility in the city of Gweru. It effectively reduced the number of factories from five (5) to four (4) in the Midlands city.

Along with streamlining its production facilities in the Midlands, Antony and his team also acquired a large herd of milk cows which DHL leased to a selected number of small-scale farmers (DHL, 2014). The plan for them, was to produce milk and supply to DHL (Phiri, 2014). An initial herd of 250 milk cows was distributed to 10 farmers with the expectation that one million litres of milk per annum will be produced (DHL, 2014). A similar leasing strategy was adopted in 2015 when DHL imported 1000 milk cows at an average cost of $\$ 2000$ per livestock (Phiri, 2016).

To complement DHL's product expansion strategy, the scaling down of facilities, and asset investments, Antony was also committed to human capital development initiatives. In his 2015 executive report to shareholders, he explained how DHL planned to unlock productivity through employee engagement. Antony emphasised the essence of building internal capabilities through targeted human capital training and development initiatives. In addition to explaining his plans for human capital development, Antony also acknowledged that DHL would have to create a conducive environment to stimulate individual and organisational creativity and innovation. 
On the basis of Antony's 2015 annual statement, employee-manager relationships had already started to improve at DHL - a development he felt was important at a time when the dairy sector was extremely unpredictable. The company's seemingly entrepreneurial approach to decision making did not only yield staff capability development, but it also encouraged 'employee buy-in' an important component for achieving organisational goals (DHL, 2015). Indeed, through various human relations initiatives and governance structures, it was reported that staff contributed to strategic cost management initiatives that went as far as wage freezes and managerial salary cuts (DHL, 2015). From a leadership perspective, this was a clear realisation that human capital was critical toward achieving DHL's strategic goals. Furthermore, training, education and human relations development programs that focused on leadership and technical skills as well as health and safety at the workplace were also initiated.

The corporate decisions Antony and his team took in anticipation for improved revenues were perhaps intended to sustain DHL as a commercially viable enterprise (Commercial Farmers Union of Zimbabwe (CFUZ), 2017; DHL, 2014). Whether the team's vision, its business development strategies, and venturing approaches were sufficient to take the enterprise back to its 1994 profitable levels, only time would tell.

\section{DHL and the Diary Sector Context in Zimbabwe}

While Antony and his team focussed on addressing inconsistencies in DHL's commercial performances, other issues surfaced elsewhere. For example, DHL faced stiff competition from other local players that included; Kefalos, Dendairy and Alpha Omega (part of former president Mugabe's Gushungo Holdings). Moreover, a direct threat to DHL emerged from imported South African (SA) milk and milk beverages. Table 2 below illustrates the value of South Africa's milk and cream products exported to Zimbabwe in 2013 as a proportion of the country's total diary exports to countries in the Southern African region. 
Table 2: South Africa's dairy market value chain profile

\begin{tabular}{|c|c|c|c|c|c|c|c|c|c|c|c|c|c|}
\hline \multirow[b]{2}{*}{ Importers } & \multicolumn{12}{|c|}{ Trade Indicators } & \multirow[b]{2}{*}{$\begin{array}{c}\text { Tariff } \\
\text { (estimated) } \\
\text { faced by } \\
\text { South Africa } \\
\text { (\%) }\end{array}$} \\
\hline & $\begin{array}{l}\text { Exported } \\
\text { value } 2013 \\
\text { (USD } \\
\text { thousand) }\end{array}$ & $\begin{array}{c}\text { Trade } \\
\text { balance } \\
2013 \text { (USD } \\
\text { thousand) }\end{array}$ & $\begin{array}{l}\text { Share in } \\
\text { South } \\
\text { Africa's } \\
\text { exports } \\
\text { (\%) }\end{array}$ & $\begin{array}{l}\text { Exported } \\
\text { quantity } \\
2013\end{array}$ & $\begin{array}{l}\text { Quantity } \\
\text { unit }\end{array}$ & $\begin{array}{l}\text { Unit value } \\
\text { (USD/unit) }\end{array}$ & $\begin{array}{c}\text { Exported } \\
\text { growth in } \\
\text { value } \\
\text { between } \\
\text { 2009-2013 } \\
\text { (\%, p.a.) }\end{array}$ & $\begin{array}{c}\text { Exported } \\
\text { growth in } \\
\text { quantity } \\
\text { between } \\
2009-2013 \\
\text { (\%, p.a.) }\end{array}$ & $\begin{array}{c}\text { Exported } \\
\text { growth in } \\
\text { value } \\
\text { between } \\
2012-2013 \\
\text { (\%, p.a.) }\end{array}$ & $\begin{array}{l}\text { Ranking of } \\
\text { partner } \\
\text { countries } \\
\text { in world } \\
\text { imports }\end{array}$ & $\begin{array}{l}\text { Share of } \\
\text { partner } \\
\text { countries } \\
\text { in world } \\
\text { imports } \\
\text { (\%) }\end{array}$ & $\begin{array}{c}\text { Total } \\
\text { import } \\
\text { growth in } \\
\text { value of } \\
\text { partner } \\
\text { countries } \\
\text { between } \\
2009-2013 \\
\text { (\%, p.a.) }\end{array}$ & \\
\hline World & 62662 & 59502 & 100 & 86740 & Tons & 722 & 33 & 39 & 117 & & 100 & 9 & \\
\hline Lesotho & 14091 & 13569 & 22.5 & 14173 & Tons & 994 & & & & 57 & 0.2 & & 0 \\
\hline Zimbabwe & 12373 & 12373 & 19.7 & 15249 & Tons & 811 & 17 & 19 & -25 & 56 & 0.2 & 16 & 40 \\
\hline Botswana & 8299 & 8299 & 13.2 & 17891 & Tons & 464 & & & & 69 & 0.1 & -22 & 0 \\
\hline Mozambique & 7844 & 7837 & 12.5 & 8190 & Tons & 958 & 26 & 16 & -2 & 91 & 0 & 7 & 9.1 \\
\hline Swaziland & 7672 & 7672 & 12.2 & 12168 & Tons & 631 & & & 45029 & 75 & 0.1 & & 0 \\
\hline Namibia & 6864 & 6864 & 11 & 13607 & Tons & 504 & & & 13628 & 71 & 0.1 & 17 & 0 \\
\hline $\begin{array}{l}\text { Tanzania, } \\
\text { United } \\
\text { Republic of }\end{array}$ & 2333 & 2333 & 3.7 & 2974 & Tons & 784 & 15 & 14 & -3 & 66 & 0.1 & 21 & 60 \\
\hline Angola & 794 & 794 & 1.3 & 457 & Tons & 1737 & 4 & -13 & 416 & 39 & 0.3 & 21 & 2 \\
\hline Zambia & 563 & 563 & 0.9 & 405 & Tons & 1390 & -32 & -31 & 196 & 156 & 0 & 29 & 0 \\
\hline Malawi & 435 & 435 & 0.7 & 356 & Tons & 1222 & 14 & 10 & 37 & 154 & 0 & -7 & 0 \\
\hline Comoros & 360 & 360 & 0.6 & 438 & Tons & 822 & -1 & 2 & -1 & 144 & 0 & 21 & 0 \\
\hline
\end{tabular}

Source: Department for agriculture and fisheries: Republic of South Africa, 2014

Evidently, the table above shows that South Africa's milk and cream exports to Zimbabwe in 2013 accounted for $19 \%$ of the country's cumulative dairy export value within the Southern African Development Community (SADC). Within this community, Zimbabwe was the third largest destination of South Africa's milk products with a financial value of $\$ 12373000$. It was therefore less-surprising that a study carried out by INVESCI concluded that, dairy products imported from SA comprised the largest amount of milk and milk beverages consumed in Zimbabwe by 2014 (INVESCI, 2014).

Although Zimbabweans were suffering from persistent economic hardships, the move to abandon the country's own currency as part of the government's 'dollarization' strategy, during the 2009 government of national unit (GNU), marginally improved the availability of financial resources in banks in Zimbabwe (Simba, Smith and Dube, 2018). Thus, the availability of financial resources meant that the country's citizens had some access to finance which temporarily boosted their purchasing abilities. 
However, because of the economic hardships they experienced before the GNU, Zimbabweans were more price savvy. This meant that DHL's competing brands especially cheaper milk products became more attractive. Dairy products that were imported from SA were more visible in Zimbabwe's main supermarkets that included; Athienitis Fife Avenue, OK Bazaars, Bon Marche, TM Pick 'n' Pay, Spar, Food World and Choppies branches in Harare, than local milk products (The Zimbabwe Independent, 2016). When compared to DHL's milk prices, SA's imported milk and milk beverages were much cheaper.

So, given the weakened state of Zimbabwe's economy, customers preferred cheaper imported dairy products from SA than DHL's relatively expensive dairy products. Moreover, the costs for producing milk beverages had risen for DHL because of its ancient equipment. In addition to reduced revenues, and operating profit, previously discussed, gross and net profit margins also took a hit. For example, DHL's Gross Profit was 24\% in 2013 down 30\% from 2012. Net profit recorded a negative figure in 2013 as compared to 2012. Figure 1 illustrates DHL's reduced profits between 2009 and 2013. Evidently, this was yet another strong signal that radical decisions were needed to turnaround the company's fortunes.

Figure 1: DHL's profit margins in the face of competition

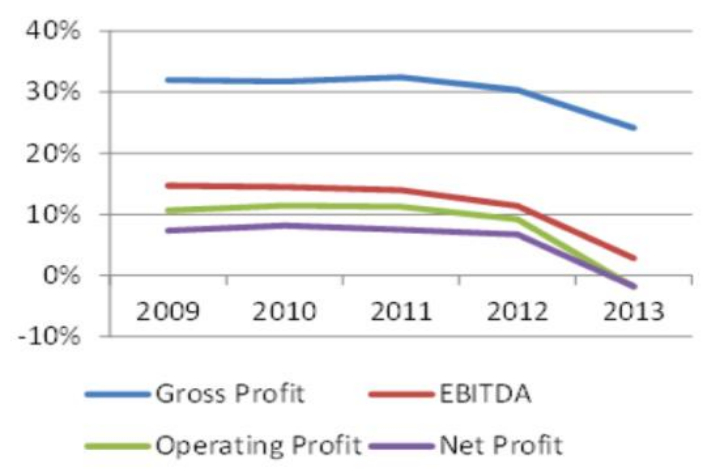

Source: INVESCI (2014) 
According to Rudzuna (2013), DHL attempted to minimise the impact of imported dairy products mainly from SA by importing toll-produced UHT milk which it rebranded "Chimombe". Although this partly ensured that DHL's brand name was visible in the dairy markets within Zimbabwe, ultimately, it was the cheaper imported milk which made DHL's milk and milk beverages lesscompetitive. Antony and his top management team admitted that their imported UHT milk was a short-term measure, but their long-term goal was to revitalise local milk production (Rudzuna, 2013). Clearly, the way the dairy market in Zimbabwe evolved demanded entrepreneurial leadership and maybe a bit of "luck"?

Despite Antony and his team's efforts in 2015/2016 toward revitalising internal business and development activities in order to be in line with market changes, in April 2017, he accepted that DHL had not made any positive gains in terms of profit margins. In the trading period that ended December 2016, DHL had made $\$ 5,4 \mathrm{~m}$ loss, from a $\$ 2,3 \mathrm{~m}$ profit recorded in the previous year, and an operating loss of $\$ 3,89 \mathrm{~m}$ from a $\$ 3,97 \mathrm{~m}$ operating profit (CFUZ, 2017; The Source, 2017) as illustrated in Table 3. 
Table 3: Statement of profit and loss account as at 31 December 2016

Revenue
Cost of sales
Gross profit
Fair value adjustment on investment property
Other operating income
Selling and distribution expenses
Administration expenses
Other operating expenses
Operating (loss)/profit
Income arising from restructuring of the Group
Finance costs
Finance income
(Loss)/profit before taxation
Income tax (expense)/credit
(Loss)/profit for the year

\begin{tabular}{|c|c|c|}
\hline & \multicolumn{2}{|c|}{ GROUP } \\
\hline & 2016 & 2015 \\
\hline \multirow[t]{4}{*}{ Notes } & US\$ & US\$ \\
\hline & $93,422,853$ & $103,441,209$ \\
\hline & $(74,506,769)$ & $(78,727,306)$ \\
\hline & $18,916,084$ & $24,713,903$ \\
\hline 11 & 83,801 & - \\
\hline \multirow[t]{3}{*}{3} & 131,480 & 238,907 \\
\hline & $(11,689,941)$ & $(9,921,234)$ \\
\hline & $(10,518,050)$ & $(10,854,985)$ \\
\hline 4 & $(821,208)$ & $(206,533)$ \\
\hline 5 & $(3,897,834)$ & $3,970,058$ \\
\hline 13.1 & - & - \\
\hline 6 & $(1,062,697)$ & $(1,085,599)$ \\
\hline \multirow[t]{2}{*}{7} & 80,025 & 127,131 \\
\hline & $(4,880,506)$ & $3,011,590$ \\
\hline \multirow[t]{2}{*}{8} & $(569,806)$ & $(709,917)$ \\
\hline & $(5,450,312)$ & $2,301,673$ \\
\hline
\end{tabular}

Source: Dairibord Holdings Limited 2016 Annual Report, p.39

However, these results were somewhat expected. In the annual report published in 2015, Antony's statement to shareholders highlighted that the macro-economic situation in Zimbabwe was not expected to improve in 2016. He pointed out high unemployment rates and household disposable income as the main factors, and stressed that incomes were expected to remain low as a consequence of stagnated wages. The drought which was experienced in 2015 was also highlighted as another contributing factor. A lack of water for irrigation as a result of drought was anticipated to trigger a rise in the cost of stock feeds. The implications for this were that, DHL was left with limited options but to import the livestock nutritional product from overseas (DHL, 2015). 
In the light of his outlook for 2016, Antony was asked by a diary industry expert at a conference in Harare, whether DHL was likely to change course and focus instead on improving existing company processes, he did not hold back. Antony stressed that the company's "restructure, expand and diversify" strategy was not going to be scaled back because he felt that the strategy was not short-term, but it was rather long-term (The Source, 2017). From an observers' perspective, one is bound to question whether this was a case of strategic misalignment?

Nevertheless, DHL pressed on; and in December of 2016 it was announced that the company will consolidate DHL, Lyons and NFB Logistics operations with effect from the beginning of January 2017 in order to reduce operations-related costs (DHL, 2016). Several factors may have triggered this rather reactive approach. The revenues generated from DHL's main product ranges were lower in 2016 as compared to 2015, regardless of the introduction of Pfuko yeMaheu, the improvements to cascade, yogburt and nutriplus facilities and restructuring attempts DHL had previously undertaken. Reduced revenues were largely driven by average selling prices which dropped from $\$ 1.24$ to $\$ 1.11$ in 2016 (CFUZ, 2017). Figure 2 illustrates these percentage changes between 2015 and 2016 amongst liquid milk (15\%), food (12\%) and beverages (3\%).

Figure 2: Revenue by product portfolio



Source: DHL, 2016 
Added to the percentage drops amongst DHL's main dairy product ranges, the volume of milk supplied to the company was also a key factor which contributed to its reduced revenues. In 2016, the supply of milk remained static, regardless of investments in milk cows carried out between 2014-2015. Figure 3 below illustrates that there was no improvement in the volume of milk supplied to DHL in 2015 and in 2016, with a 4\% reduction in dairy food products and 1\% drop in milk beverages between 2015 and 2016 recorded.

Figure 3: Volume changes amongst DHL's product range between 2015 and 2016

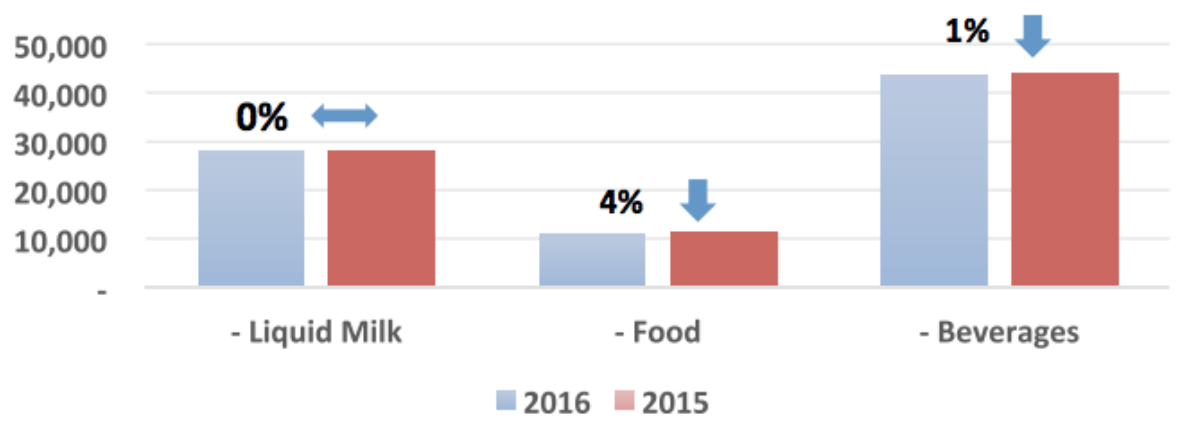

Source: DHL, 2016

Furthermore, the performance of DHL's business unit in Malawi (DML) was below expectations. Antony pointed to shrinking consumer disposable incomes and reduced donor support in their Dairibord Malawi Limited's (DML) operations as some of the factors that continued to hinder DHL's recovery efforts. Also, the floods in Malawi at the beginning of 2016 impeded market accessibility. As a result of these factors, the SBU's contribution to Group revenues was at 3\% with an operating loss of $\$ 200000$ (DHL, 2016). For DML business unit, Antony and his team took a step back from implementing what had become a habit at the company of instantaneously "restructure, expand and diversify". Was this perhaps a sign of a strategy rethink and the new approach going forward? 


\section{The Future for DHL}

As much as the present (2017) change in the political arena in Zimbabwe may provide some hope for DHL, it might also give rise to more problems. The pragmatic approach to economic matters the new President Mr Emmerson Mnangagwa has long been associated with (FT, 2017), may further liberalise the dairy business environment in Zimbabwe while simultaneously inviting competition for DHL from elsewhere. A closer look at the situation which was created by SA's imported milk and milk beverages in the consumer market, in Zimbabwe, liberalising the business environment might further expose DHL. Such exposure would have huge implications for the dairy company in that, DHL would be forced to find new ways for taking its products to the market rather than reprising its "restructure, expand and diversify" strategy.

Another question for DHL going forward will be about whether the current leadership still has the vision to take the business in a new direction. Particularly, does Antony and his management team have the entrepreneurial mind set needed to navigate DHL through the unpredictable business terrain in Zimbabwe's dairy market, while mapping its future strategy. In the light of the demand for UHT-sterilised milk Chimombe emerging from Namibia (ZimTrade, 2015) - a country to the West of Zimbabwe, Antony and his team may need to consider formulating a deliberate strategy to take advantage of this new market opportunity. Perhaps, an entrepreneurial decision would potentially turn Antony's short-term strategy related to imported UHT-milk (Chimombe) from being a way of boosting brand awareness in the local market to a viable product expansion strategy into Namibia. 


\section{Epilogue}

Generally, articulating entrepreneurial decisions in organisations has always been a challenge regardless of their size. The process is often complicated by rapidly changing market conditions. In the context of DHL, it was clear that Antony and his top management team faced intractable operations management related issues, and macro-economic conditions that demanded an entrepreneurial mind set. A real threat for DHL emerged from milk and milk beverages that were imported from South Africa. This was further exacerbated by the deteriorating political and socioeconomic conditions (Simba, Smith and Dube, 2018) ranging from; weakened multi-lateral relations, reduced disposable incomes to currency depreciations in their markets within the southern African region.

Additionally, Zimbabwe's former President Robert Mugabe’s ill-conceived Statutory Instrument (SI) 64 of 2016 did not help. It basically restricted the importation of many products including milk into Zimbabwe (The Standard, 2016). As Antony and his team were searching for commercial solutions to improve DHL's performance, such a protectionist approach severely limited the dairy company's business options. Perhaps, an entrepreneurship approach was a realistic option in such conditions, for DHL. Clearly a corporate decision had to be made.

Other than its reprised "restructure, expand and diversify", DHL's only other strategy of importing UHT-sterilised milk which it branded Chimombe failed to completely revitalise its commercial performance. May be Antony and his team required to seriously assess their position and consider alternative strategies? 
Alternative, local milk suppliers such as; Kefalos, Dendairy and notably Alpha Omega (part of president Mugabe's Gushungo Holdings) may have also added to the complicated mix in the diary market in Zimbabwe, because of their nature and characteristics. Furthermore, a chaotic land redistribution exercise in 2009, destabilised a reliable milk supply-chain for DHL. Because peasant farmers who were less-equipped with little expertise were left in charge of milk producing systems. This consequently, led to reduced milk volumes. The droughts of the 90s and especially the 2015 experience did not help the desperate situation at DHL.

Efforts to revitalise internal business operations saw Antony and his top management team resort to cost cutting-measures at DHL, but still the results were largely mixed. Even in the face of inconsistent results, DHL invested in assets. For example, the dairy company purchased milk cows and leased them to accredited small-scale farmers. Was this perhaps a start of a fightback, by DHL, to take the initiative in the dairy market in Zimbabwe?

Nevertheless, the introduction of a new beverage e.g. Pfuko yeMaheu and the commissioning of Nutriplus and Yoghurt facilities in Chitungwiza only achieved modest performance improvements. Maybe, strategies for getting employees engaged in the creativity and innovation process with the view to improving internal processes somewhat demonstrated a hint Antony's entrepreneurial touch? This was also complemented, to some extent, by continued employee up-skilling and development, and the desire to create a conducive environment for creativity.

The challenges faced at DHL and the approaches for improving business processes indicated an immediate need for undertaking drastic entrepreneurial decisions in enterprises, in general. As such, a key question that may still remain for DHL is that, given its "restructure, expand and diversify" legacy, would there be a call for making more radical, risky but calculated decisions as opposed to a continued reprising of the same strategies that were largely reactive? 
Maybe, Antony and his team needed to hold back their satiable desire for persistently restructuring DHL, and carefully consider entrepreneurship decisions that were more aligned to DHL's core values while revolutionising the dairy industry. After all, it was a matter of entrepreneurial decision making!

\section{References:}

Binns, D., and Winslow, K., (1997). Case Study Analysis: The Privatization of Dairibord Zimbabwe, Ltd. and the Role of the Dairibord Employee Stock Ownership Trust, Final Report U.S. Agency for International Development, Private Enterprise Development Support Project I11, Coopers and Lybrand, L.L.P. Available at: http://pdf.usaid.gov/pdf docs/PNACB779.pdf, Accessed on 13/12/2017

Chamboko, T., and Mwakiwa, E., (2016). A review of smallholder dairy development in Zimbabwe 1983 to 2013: the effect of policies, Livestock Research for Rural Development 28 (6), pp. 1-18.

Commercial Farmers Union of Zimbabwe, (2017). Dairibord Zim sees improved performance, Available at: http://www.cfuzim.org/ cfuzimb/index.php/newspaper-articles2/finance-and-economics/8516-dairibord-zim-sees-improved-performance, Accessed on 18.12.2017.

Department for agriculture and fisheries: Republic of South Africa, (2014). A profile of the South African Market Value Chain, Directorate Marketing, Available at: http://www.nda.agric.za/doaDev/sideMenu/Marketing/Annual\%20Publications/Com modity $\% 20$ Profiles/Livestock/Dairy $\% 20$ market $\% 20$ value $\% 20$ chain $\% 20$ profile $\% 202014$. pdf, Accessed on. 03.03.2018.

DHL, (2017). History of Dairibord Holdings Limited, Available at: https://www.dairibord.com/company-overview/company-history/history-of-dairibordholdings-limited/, Accessed on 14.12.2017.

DHL, (2014). Annual and Interim Reports, Available at: https://www.dairibord.com/financialreports/\#1494237055028-94fd8bd0-8fc2, Accessed on 13.12.2017.

DHL, (2015). Annual Report, Available at: https://www.dairibord.com/data/2017/05/dairibord annual report 2015.pdf, Accessed 19.12.2017.

FT, (2013). Zimbabwe's indigenisation policy: falling apart? Available at: https://www.ft.com/content/08b85cf2-e77c-3fee-9d32-9af8e6e5a790, Accessed on 22.12.2017

Godana, T., and Hlatshwayo, B. (1998). Public enterprise reform and privatisation in Zimbabwe: Economic, legal and institutional aspects. Zamberia, 25, pp. 1-28, Available at: http://journals.co.za/docserver/fulltext/zambezia/25/1/338.pdf?expires=1513383381 \&id=id\&accname $=$ guest\&checksum $=7$ B88ED3CA8E4E26E4D07BF2ADB6F8DF9, Accessed on: 16.12.2017.

Hanyani-Mlambo B. T., Sibanda, S, and Østergaard, V., (1998). "Socio-economic aspects of smallholder dairying in Zimbabwe", Livestock Research for Rural Development 10(2). Available at: http://www.fao.org/livestock/agap/frg/lrrd/lrrd10/2/zimb102.htm, Accessed 19.12.2017. 
Hanyani-Mlambo, B. T., (2000). "Smallholder Dairy Production and Marketing in Zimbabwe: A Socio - Economic Study of the Gokwe, Rusitu and Marirangwe Dairy Development Projects", WORKING PAPER AEE 3/2000, Department of Agricultural Economics and Extension, University of Zimbabwe, pp.1-13.

INVESCI (2014) "Dairibord Holdings Limited Half Year Results", Dairibord-Research-Note-HY2014, Available at: www.invesci.com/articles/Dairibord-Research-Note-HY-2014.pdf Accessed on: 18.12.2017.

Jaravaza D., C., Maluleke, N. and Magonde S., (2014). "The Impact of Advertising of Brand Equity, Nutriplus Beverage, On the Performance of the Manufacturing Company", International Journal of Management Sciences and Business Research 3(8), pp. 13-19 ISSN (22268235)

Johnson, G. Whittington, R. Scholes, K. Angwin D. and Regner, P., (2014). Exploring Strategy: Text and Cases, $10^{\text {th }}$ Edition, Pearson Education Limited, Hallow: UK.

Makamure, (2001) “Liberalisation of Agricultural Markets", Unpublished consultancy report SAPRI/Zimbabwe.

Marazanye, K., (2016). An Analysis of Indigenisation and Economic Empowerment in Zimbabwe, Thesis presented in partial fulfilment of the requirements for the degree Masters in Public Administration in the Faculty of Economic and Management Science at Stellenbosch University. Stellenbosch University Library, Available at: https://scholar.sun.ac.za/handle/10019.1/100093, Accessed on 20.12.2017.

Masunungure, E, and Zhou, D., (2006). "An Analysis of the Objectives and Effects of Privatisation on the Public Sector and the Role of the State in Zimbabwe", Zimbabwe Coalition on Debt and Development, (ZIMCODD) and The Southern Africa People's Solidarity Network, (SAPSN). Harare. ISBN: 0-7974-3229-9.

Mupunga, E, G., (1994). Impact of the Dairy Development Programme on the living standards of small-holder farmers in Zimbabwe: a case study of Nharira Small-holder Dairy Development Project. Unpublished MBA Thesis.

Muir-Leresche, K., and Muchopa, C. (2006). Agricultural marketing. University of Zimbabwe (UZ) Publications/Michigan State University (MSU). Available at: https://opendocs.ids.ac.uk/opendocs/bitstream/handle/123456789/8969/MuirLeresche, \%20Prof. $\% 20 \mathrm{Kay} \% 20 \% 26 \% 20$ Muchopa, \%20Chiedza, \%20Agricultural $\% 20 \mathrm{Ma}$

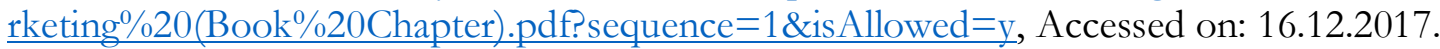

Phiri, E., (2014). “An Assessment of Zimbabwe's Dairy Sector”, Available at: https://www.academia.edu/9668624/An Assessment of Zimbabwes Dairy Sector, Accessed on 19.12.2017.

RBZ, (2007). Unlocking value through privatisation of targeted public enterprises, Supplement to the January 2007 Monetary Policy Review, Available at: http://www.rbz.co.zw/assets/public-enterprises.pdf, Accessed on 28.12.2017

Rudzuna, C., (2013). "Dairibord results expose industry", Commercial Farmers Union of Zimbabwe, Available at: http://www.cfuzim.org/ cfuzimb/index.php/agriculture/3553-dairibordresults-expose-industry, Accessed on 18.12.2017

Slack, N., Brandon-Jones, A., and Johnston, R., (2016). Operations Management, $8^{\text {th }}$ Edition, Pearson Education, UK. ISBN 9781292098678.

Simba, A., Smith, D. and Dube, T., (2018). Competing with the Grey Market: Puzey and Payne in Zimbabwe, The CASE Journal, Print Published: 05-Mar-2018 14(2) (In Press).

The Source, (2017). "Mandiwanza dark mood reflects Dairibord's travails", Available at: http://source.co.zw/2017/04/mandiwanzas-dark-mood-reflects-dairibords-travails/, Accessed on: 18.12.2017. 
The Standard, (2016). SA hits back at Zim imports ban, Available at: https://www.thestandard.co.zw/2016/08/07/sa-hits-back-zim-imports-ban/, Accessed on 05.03.2018

The Zimbabwe Independent (2016). 'Mugabe's dairy bits hard times", Zimbabwe Situation, Available at: http://www.zimbabwesituation.com/news/zimsit-m-mugabes-dairy-hitshard-times-the-zimbabwe-independent-2/, Accessed 01.12.2017.

ZimTrade, (2015). UHT Full Cream Milk in Tetra packs to Namibia, Available at: zimdev.citc.mu/wp-content/.../Namibia-Market-Point-for-UHT-Full-Cream-Milk, Accessed on. 04.03.2018

Zvomuya, F., (2009). Power or milk drain, Dairy Mail Africa: Publication for the Dairy Industry in Africa 4(2), 1 August 2009, pp. 12-17(6). 


\section{Instructor Manual}

\section{Key Points, Suggested Teaching Plan and Case Summary}

Since the colonial era, Dairibord Holdings Limited has undergone significant changes in Zimbabwe. One being from a SOE to a public limited company. Other than changing its form of ownership from DMB to DZL and then DHL, political and macro-economic factors in the dairy market in Zimbabwe have conspired to influence its commercial activities. Additionally, in a country that is perhaps considered to be still in the 'valley of death' meaning that it is at a stage of economic development which is dominated by limited industrialization and economic stagnation, DHL's commercial activities were significantly restricted. Perhaps, government policy interventions, at this stage of its economic development, were a prerequisite for the country's modernization. An immediate and direct threat for DHL emerged from imported milk and milk beverages from South Africa. Local competitors were also a factor which militated inconsistent performances DHL recorded between 2009 to 2016. The likes of Kefalos, Dendairy and Alpha Omega (part of former president Mugabe's Gushungo Holdings) further intensified competition in the dairy industry in Zimbabwe.

The governments' chaotic Economic Structural Adjustment Program (ESAP) (Marazanye, 2016; Masunungure and Zhou 2006) liberalized Zimbabwe's market and exposed DHL to small scale milk producing farmers. Natural causes including drought in the early 90s and part of 2015 did not help DHL's cause either. Livestock feed became scare locally which meant that it had to rely on foreign expensive cow nutrients. The chaotic land redistribution also contributed to reduced milk volumes in Zimbabwe. Its legacy was land left in the hands of ill-equipped peasant farmers who could not produce sufficient milk volumes to meet the demand, hence limited milk supplies to DHL. Internally, DHL's ancient milk producing equipment also affected the volume of milk it could process at any given point. 
Ever-since DHL's privatization in 1997, Antony and his top management team have been on the back foot trying to catch up with events in the ever-changing dairy market.

The "restructure, expand and diversify" strategy Antony and his team adopted to reduce the impact of the various factors highlighted above never quite worked. Precisely, it failed to fully restore the enterprise back to its profitable status it enjoyed during the period leading to its privatization, when an elected board of directors turned it around from a company with $Z \$ 60$ million deficit to a profitable enterprise.

It was also clear in the narrative about DHL that Antony and his team had become accustomed to similar strategies where they would restructure their facilities while simultaneously expanding the product range as well as diversifying into other product lines. This combination of strategies was reprised over and over again. For example, in 2015 the team streamlined DHL's facilities in Gweru by closing one of the factories leaving 4 factories. In Mutare and Bulawayo, DHL's 'rationalisation process' meant that some of the factories and operations in those cities were relocated to the capital city Harare, and a nearby town of Chitungwiza. While this was taking place, the team opened a sterilised milk facility in Chipinge - a city to the south east of the Zimbabwe and it simultaneously introduced a new traditional beverage which was branded Pfuko yeMaheu and was processed at its Chitungwiza factory (DHL, 2017; The Source, 2017).

To improve internal processes, Antony and his team also tried to create an entrepreneurial environment at DHL. Employees were invited to contribute their creative and innovative ideas and training programs were initiated to enhance their capabilities. Evidently, DHL tried several strategies in an attempt to withstand the challenges it encountered in Zimbabwe. The narrative about DHL provided hints that pointed to the importance of an entrepreneurial mindset in markets that are highly unpredictable such as the dairy markets in Zimbabwe. 
Students should be encouraged to consider radical entrepreneurial decision-making approaches that are more proactive, risky but calculated to allow companies like DHL to gain competitive advantage and improve their revenues subsequently boosting their profit margins. Also, students should be encouraged to consider entrepreneurial leadership and its multi-dimensional constructs that include: entrepreneurship, management and leadership (Simba, Smith and Dube, 2018). Being reactive and a lack of strategic options may be an undesirable combination, especially in markets such as the dairy sector in Zimbabwe. A reactive approach and a lack of a contingency planning was demonstrated by Antony when he categorically stated that DHL's reprised strategy (restructure, expand and diversify) was not going to change regardless of a poor outlook for 2016. This perhaps indicated a lack of vision needed to revitalize (Hamel and Prahalad, 1989) DHL in a transient market such as the dairy sector in Zimbabwe.

In the light of the above, students' views about what Antony would have considered to ensure DHL was better prepared for 2016 going forward, should produce a stimulating and interesting debate about entrepreneuring, changing, strategizing and investing (De Wit and Mayer, 2014; Simba and Nyandoro, 2016). Indeed, the case provides students with an opportunity to assess DHL's external conditions and to consider what DHL should do to gain competitive advantage when faced with adversity. It is indeed, a matter of entrepreneurship at DHL.

In order to fully explore various entrepreneurship issues arising from the case study the following approach should be adopted:

- Student should be given an opportunity to read the case study before the session. Also, it is advisable to set up a discussion board on your institution's learning platform to allow student to share ideas about the case with an instructor's support. 
- The session should start with an instructor-led discussion on how entrepreneurial leadership, strategic entrepreneurship and entrepreneurial decisions are essential in rapidly changing market conditions.

- Students should be put into groups of $4 \mathrm{~s}$ or $5 \mathrm{~s}$ to discuss their understanding of the narrative in the case. A question and answer technique should be used as a strategy for structuring group discussions.

- While still working in their groups, students should be instructed to consider the attributes of an organization that demonstrates an entrepreneurial approach. Moreover, they should also be encouraged to think about the cognitive modes of individuals with an entrepreneurial mindset.

- Prompt students to identify and debate DHL's corporate venturing, strategic management and new product development strategies.

- Also, students should be instructed to construct a mind map, on a A3 paper, to highlight their main thoughts and ideas about the events, in the case, that require an entrepreneurship touch.

- To wrap up group discussions, a plenary should be used drawing on the entrepreneurial decisions at DHL and this should be linked with existing theories including Kuratko's (2014) Theory, Process and Practice.

The table below details an adaptable lesson plan to guide the discussion surrounding DHL's narrative.

\section{Lesson Information \\ Course Title: \\ Module Title: \\ Lesson date and time: \\ Location: \\ Number of students:}

$\operatorname{Aim}(\mathrm{s})$ of the lesson:

Learning Objectives:

By the end of the lesson students will have had the opportunity to: 
LO1: identify the features of an organisation with an entrepreneurial mind set;

LO2: evaluate the importance of making entrepreneurial decisions in a rapidly changing market such as the dairy industry in Zimbabwe;

LO3: explore the sort of issues faced by large enterprises in establishing an entrepreneurial architecture;

LO4: develop an appreciation of the importance of practicing entrepreneurial leadership in rapidly changing business conditions; LO5: analyse the importance of developing an effective strategy while considering strategic options necessary to withstand markets such as the dairy sector in Zimbabwe that are characterised with rapid changes.

\begin{tabular}{|c|c|c|c|c|c|}
\hline Timings & Activities & LOs & What tutor does & What students do & Resources \\
\hline $\begin{array}{l}5-10 \\
\text { mins }\end{array}$ & Instructor-led discussion & & $\begin{array}{l}\text { Introduce the notion of entrepreneurship, } \\
\text { business management and entrepreneurial } \\
\text { decision-making. Use the context of constantly } \\
\text { changing markets such as the dairy sector in } \\
\text { Zimbabwe }\end{array}$ & $\begin{array}{l}\text { Listening \& note } \\
\text { taking }\end{array}$ & $\begin{array}{l}\text { PowerPoint, } \\
\text { Interactive } \\
\text { whiteboard, } \\
\text { board markers }\end{array}$ \\
\hline $\begin{array}{l}7-10 \\
\text { mins }\end{array}$ & $\begin{array}{l}\text { Students recapping the main } \\
\text { events in the case study } \\
* * \text { Students should have been } \\
\text { given the chance to read the } \\
\text { case prior to the session } \\
\text { without the questions. }\end{array}$ & LO1 & $\begin{array}{l}\text { Prompt students by using leading questions for } \\
\text { them to identify the business and management } \\
\text { activities of DHL and they should be encouraged } \\
\text { to contrast this with the features of an } \\
\text { organisation with an entrepreneurial mind set e.g. } \\
\text { Econet in Zimbabwe and MTN in South Africa }\end{array}$ & $\begin{array}{l}\text { Reading and } \\
\text { highlighting the main } \\
\text { themes }\end{array}$ & $\begin{array}{l}\text { Hard copies of } \\
\text { the case study, } \\
\text { highlighters, } \\
\text { note books and } \\
\text { electronic } \\
\text { devices, laptops }\end{array}$ \\
\hline $\begin{array}{l}3-5 \\
\operatorname{mins}\end{array}$ & $\begin{array}{l}\text { Setting-up the room to } \\
\text { facilitate group working }\end{array}$ & & $\begin{array}{l}\text { Instruct students to form groups of } 4 \mathrm{~s} \text {. Intervene } \\
\text { where appropriate to ensure that groups consist } \\
\text { of students with a range of abilities }\end{array}$ & $\begin{array}{l}\text { Moving to sit in } \\
\text { allocated groups }\end{array}$ & $\begin{array}{l}\text { Tables and } \\
\text { chairs }\end{array}$ \\
\hline $\begin{array}{l}20-25 \\
\operatorname{mins}\end{array}$ & $\begin{array}{l}\text { Students watch a video } \\
\text { entitled: Dairiboard CEO } \\
\text { Antony Mandiwanza speaks } \\
\text { on the benefits of SI } 64 \text { of } \\
2016 \text { \#263Chat } \\
\text { Encourage students to take } \\
\text { notes concerning } \\
\text { management and business } \\
\text { development in the dairy } \\
\text { industry in Zimbabwe. }\end{array}$ & $\begin{array}{l}\text { LO2 } \\
\text { LO3 } \\
\text { LO4 }\end{array}$ & $\begin{array}{l}\text { Explain the macro-economic conditions } \\
\text { prevalent in developing and emerging economies. } \\
\text { Focusing on the political, socio-economic } \\
\text { conditions in Zimbabwe. More importantly, } \\
\text { highlight the strategies Antony has highlighted } \\
\text { are being implemented at DHL to limit the } \\
\text { impact of their operational challenges and } \\
\text { external factors on the company's profitability. } \\
\text { Also, highlight the importance of making } \\
\text { entrepreneurial leadership and entrepreneurial } \\
\text { decision-making in rapidly changing markets. } \\
\text { In groups of 4s instruct students to produce a list } \\
\text { of factors highlighted in the video which were } \\
\text { affecting DHL's commercial activities in } \\
\text { Zimbabwe. }\end{array}$ & $\begin{array}{l}\text { Listening and taking } \\
\text { notes. Answering } \\
\text { questions. Group } \\
\text { work - brainstorming } \\
\text { and sharing video } \\
\text { observations. }\end{array}$ & $\begin{array}{l}\text { Interactive } \\
\text { whiteboard, } \\
\text { You-tube video } \\
\text { A3 paper, pen, } \\
\text { laptops }\end{array}$ \\
\hline $\begin{array}{l}15-20 \\
\operatorname{mins}\end{array}$ & $\begin{array}{l}\text { Students to discuss alternative } \\
\text { strategies Antony and his top } \\
\text { management could have } \\
\text { considered instead of carrying } \\
\text { on with the "restructure, } \\
\text { expand and diversify" strategy }\end{array}$ & LO5; & $\begin{array}{l}\text { Interact with the students. Prompting them to } \\
\text { consider elements of strategic entrepreneurship, } \\
\text { strategic management in rapidly changing market } \\
\text { conditions. Encourage them to consider the } \\
\text { economic climate and the imported milk and } \\
\text { milk beverages from South Africa. Also point } \\
\text { them to the emergence of small-scale farmers } \\
\text { and the impact of policies such as the } 2008 \\
\text { indigenisation. }\end{array}$ & $\begin{array}{l}\text { Brainstorming, } \\
\text { exchanging ideas, and } \\
\text { constructing mind } \\
\text { maps }\end{array}$ & $\begin{array}{l}\text { A3 paper, note } \\
\text { books, pen, } \\
\text { laptops }\end{array}$ \\
\hline $\begin{array}{l}15-20 \\
\operatorname{mins}\end{array}$ & $\begin{array}{l}\text { Students answering case-based } \\
\text { questions }\end{array}$ & $\begin{array}{l}\text { LO1; } \\
\text { LO2; } \\
\text { LO3 } \\
\text { LO4; } \\
\text { LO5 }\end{array}$ & $\begin{array}{l}\text { Interact with the students. Use leading questions } \\
\text { to help students identify answers in the case as } \\
\text { well extrapolate their interpretations in a wider } \\
\text { context. }\end{array}$ & $\begin{array}{l}\text { Discussing and writing } \\
\text { their responses }\end{array}$ & $\begin{array}{l}\text { Flip chart, board } \\
\text { markers }\end{array}$ \\
\hline $\begin{array}{l}7-10 \\
\operatorname{mins}\end{array}$ & $\begin{array}{l}\text { Students to take a lead } \\
\text { highlighting their thoughts } \\
\text { about the case study }\end{array}$ & $\begin{array}{l}\text { LO4; } \\
\text { LO5 }\end{array}$ & $\begin{array}{l}\text { Prompting groups to provide feedback to the rest } \\
\text { of the class. }\end{array}$ & $\begin{array}{l}\text { Students presenting } \\
\text { their answers }\end{array}$ & Flip chart \\
\hline 5 mins & Plenary & & Recap the main points & $\begin{array}{l}\text { Students answering } \\
\text { questions }\end{array}$ & $\begin{array}{l}\text { PowerPoint, } \\
\text { Interactive } \\
\text { Board }\end{array}$ \\
\hline
\end{tabular}




\section{Case study discussion questions}

\begin{tabular}{|c|c|}
\hline Entrepreneurship Discussion questions & Management Discussion Questions \\
\hline $\begin{array}{l}\text { (1) Can DHL be considered an organization with an } \\
\text { entrepreneurial mind set? Explain your answer. }\end{array}$ & $\begin{array}{l}\text { When DHL was still known as DMB, a board of directors } \\
\text { appointed by the government restructured its operations between } \\
1991 \text { and 1994, and by } 1997 \text { the company was turned into a profitable } \\
\text { enterprise and its was subsequently renamed DZL. Why do you think } \\
\text { its reprised "restructure, expand and diversify" strategy failed to work } \\
\text { for DHL as from } 2000 \text { to } 2016 \text { ? }\end{array}$ \\
\hline $\begin{array}{l}\text { (5) "The way the dairy market in Zimbabwe evolved required } \\
\text { entrepreneurial leadership and maybe a bit of luck? Do you agree or } \\
\text { disagree? Explain you answer. }\end{array}$ & $\begin{array}{l}\text { (3) What would Antony and his management team have done } \\
\text { differently to turnaround DHL to profitability between } 2009 \text { to } 2016 \text { ? }\end{array}$ \\
\hline $\begin{array}{l}\text { The volume of milk supplied to DHL dwindled following the } \\
\text { drought, and farm invasions. Other than investing in more milk cows, } \\
\text { what would you have advised Antony and his team to do to increase } \\
\text { the supply of milk? }\end{array}$ & $\begin{array}{l}\text { What was the main reason for converting DZL into a holding } \\
\text { with stand-alone subsidiaries known as strategic business units } \\
\text { (SBUs)? }\end{array}$ \\
\hline $\begin{array}{l}\text { What other alternative strategies that Antony and his team } \\
\text { would have utilized to increase the visibility of DHL's milk and milk } \\
\text { beverages in supermarkets in Zimbabwe instead of importing UHT- } \\
\text { sterilized milk it branded "Chimombe"? }\end{array}$ & $\begin{array}{l}\text { (6) Why do you think the introduction of a new traditional } \\
\text { beverage Pfuko yeMaheu and the expansion of facilities to produce } \\
\text { nutriplus and yoghurt only achieved modest results? }\end{array}$ \\
\hline $\begin{array}{l}\text { (9) Did Antony demonstrate an entrepreneurial touch at DHL? } \\
\text { Either you agree or disagree, highlight the decisions he made or } \\
\text { should have made to demonstrate entrepreneurship. }\end{array}$ & \\
\hline
\end{tabular}

\section{Model answers}

The model answers provided below should be used for guidance purposes. It is advisable to acknowledge reasoned and logical students' interpretations of the narrative in the case study.

(1) Can DHL be considered an organization with an entrepreneurial mind set? Explain your answer.

\section{Answer.}

Some students would point out that there is a hint that Antony and his top management team were trying very hard to create a culture that would stimulate creativity and innovation by taking suggestions and ideas about business process improvements from their employees. Other students would argue that Antony and his team would have done more. For example, Antony and his top management team should have set explicit innovation goals mutually agreed on by the employees and his team so that specific steps can be achieved. A system of feedback and positive re-enforcement should have been created. This would have made potential innovators to realize that acceptance and reward exist. 
The team should have also emphasized on individual responsibility. Confidence, trust, and accountability are key features of success in an entrepreneurial organization.

Rewards should have been used as an incentive for creativity with regards to business processes. This is also linked to encouraging risk-taking behavior which was badly needed at DHL.

Theory: Kuratko (2014) on entrepreneurial mind set in organizations would be an appropriate source to use

(2) When DHL was still known as DMB, a board of directors appointed by the government restructured its operations between 1991 and 1994, and by 1997 the company was turned into a profitable enterprise and its was subsequently renamed DZL. Why do you think its reprised "restructure, expand and diversify" strategy failed to work for DHL as from 2000 to 2016?

\section{Answer:}

The market conditions were different, $\mathrm{DMB}$ as it was known then it was the only major player in the dairy -a legacy from its colonial past. There was no competition and DMB monopolised the market. Also, the economy was relatively sound. As from 1999 land invasions and a host of other factors including less efficient equipment, intensive competition, political, socio-economic issues, and natural disasters conspired to influence DHL's commercial performance. Students may consider Timmons (1978) entrepreneurial process model. Timmons model highlights that entrepreneurial organisations must pay attention to external conditions in order to develop an appropriate business plan consummate with the market needs. For DHL, clearly the market conditions had changed. The dairy market was more open inviting more competition and cashstrapped customers were looking for cheaper options. Its reprised "restructure, expand and diversify" strategy needed to be paused like what Antony and his team ended up doing with respect to their DML underperforming SBU and carefully scan the market before making any decisions.

(3) What would Antony and his management team have done differently to turnaround DHL to profitability between 2009 to 2016?

Since the market conditions had significantly changed in the dairy market in Zimbabwe prior to 2000. The first thing Antony and his management team should have done was to construct a business model canvas (BMC) to use for business management. Their BMC should have included; value proposition, customer segments, channels, customer relationships, revenue streams, key activities, key resources, key partners and cost structures. 
The top management team should have then used this as a structured brainstorming tool to define and understand the strategic focus and the questions that needed to be answered for each of the nine building blocks.

Furthermore, establishing entrepreneurial networks would have assisted DHL in terms of sharing R\&D costs for example. It would also have brought in new and innovative ideas to the business. Their equipment was also ageing and as such a well-established business partner would potentially contribute state-of-the art equipment thereby alleviating DHL's processing issues. Also, entrepreneurial networks would have given DHL an opportunity to develop unique skills, knowledge and capabilities needed to deal with external competition. Maybe their ill-conceived idea about importing UHT-sterilised milk would have been done differently through a strategic partner.

A radical and debatable thought would be to change the management completely because its reprised "restructure, expand and diversify" strategy had not worked, and the top management team appeared to have run out of options.

Theory: Mariotti and Glackin (2016) on business model canvas; Wright and Mosey (2007) on entrepreneurial networks; Slack and Lewis (2008) on supply-chain management. Burns (2014) on Change management

(4) What was the main reason for converting DZL into a bolding with stand-alone subsidiaries known as strategic business units (SBUs)?

\section{Answer:}

SBUs are a part of the organisation for which there is a distinct external market for goods or services that are different from one another. The concept of SBUs may have been appropriate for DHL in terms of reflecting the diversity of the company's milk products and the markets it actually served. SBUs should have also enabled DHL to make strategic choices and have options in the market. Whether the company used SBUs for strategic reasons is not clear. But, what is explicit is that converting DZL into stand-alone subsidiaries as part of the DHL's "rationalisation" strategy was purely an exercise for streamlining less-commercially viable services at the company. What was confusing however with regards to their "rationalisation" strategy was its logic. As from the 2012 there was a "botchpotch" of strategies as described in the case study. Their strategy formulation approach was reactive and can be described as haphazard, at best. 
Theory: Johnson et al (2014) on exploring corporate strategy; Shepherd and Patzelt (2017). Trailblazing in entrepreneurship: Creating new paths for understanding the field.

(5) "The way the dairy market in Zimbabwe evolved required entrepreneurial leadership at DHL and maybe a bit of luck? Do you agree or disagree? Explain you answer.

\section{Answer:}

Most student would agree that the changes that took place in the dairy industry in Zimbabwe have often been rapid and required Antony to demonstrate entrepreneurial leadership at DHL. Particularly, he should have embraced more the holistic approach to business management which combined entrepreneurship and leadership. That is, a combination of strategic visioning, strategic reasoning, strategic venturing, and strategic alignment. Clearly, doing so would have helped him to assume an entrepreneurial orientation while demonstrating his leadership capabilities. Moreover, this entrepreneurial approach would facilitate system renewal, system exploitation and system protection, thereby operating as anchor points that would have been relevant in terms of turning around DHL's inconsistent commercial performance.

Floods, farm invasions, and the drought in 2015 that happened after DHL had invested in milk cows were situations beyond its control. So, a bit of luck with such situations would was needed. Notwithstanding such a conclusion, other students may consider that the emphasis on geographic indicators and ethnic and indigenous breeds is an opportunity Anthony and his team can take advantage of and consider importing native African breeds including Sanga and Zenga to use as milk sources during draught seasons because of their tolerance and immunity levels. Doing so, could be seen as an entrepreneurial solution to the draught-related breeding issues DHL endured in 2015. Also, given the open business approach adopted by the new President, other export markets surrounding Zimbabwe (e.g. the SADC region) may be a target for "ethnic milk" that would come from these African breeds.

Theory: Leitch et al. 2013; Ireland et al. (2003) on A Model of Strategic Entrepreneurship: The Construct and Its Dimensions; Ireland et al. (2009) on Conceptualizing corporate entrepreneurship strategy. 
(6) Why do you think the introduction of a new traditional beverage Pfuko yeMaheu and the expansion of facilities to produce nutriplus and yoghurt only achieved modest performance results?

\section{Answer:}

A combination of socio-economic hardships experienced by the people in Zimbabwe and the external competition from South Africa's imported cheap milk and milk beverages were the main factors that contributed to DHL's reduced revenues. As much as Pfuko yeMaheu was localized, a cheaper option from South Africa attracted more attention than the often-expensive DHL's products. This was further exacerbated by competition from other local players that included Kefalos, Dendairy and Alpha Omega (part of former president Mugabe's Gushungo Holdings). The unofficial use of the USD meant that cash reserves in the major banks were eroded thereby limiting the availability of cash for potential DHL customers.

Given the lack of disposable income and the general decline in living standards for the vast majority of Zimbabweans products such as nutriplus and yoghurt were very much seen as luxury and consumers prioritized other essential commodities.

(7) The volume of milk supplied to DHL dwindled following the drought, and farm invasions. Other than investing in more mille. cows, what would you have advised Antony and his team to do to increase the supply of milk?

\section{Answer:}

To start with, the idea of leasing cow milk was a good plan. However, to be in control and better manage the flow of milk DHL needed acquire (outright purchase) efficient and well-developed small-scale units. This approach would effectively provide an option to complement DHL's SBUs. Further, Antony and his team would have taken some calculated risks by looking for opportunities beyond the company's immediate boundaries. Although the unit DML had provided its fair share of problems, other more stable and economically viable countries that are geographically nearby such as Zambia, Botswana and Namibia would have offered DHL different entrepreneurial opportunities.

Theory: Rae (2014) Opportunity-led entrepreneurship

(8) What other alternative strategies that Antony and his team would have utilized to increase the visibility of DHL's milk and milk beverages in supermarkets in Zimbabwe instead of importing UHT-sterilized milk it branded "Chimombe"? 


\section{Answer:}

One of the strategies that Antony and his team would have utilized to increase visibility is by having their own Dairibord branded express shops and mobile units. Also, they should have considered intensifying their presence on social media especially on whatsup which seems to be dominant in Zimbabwe. This would have been achieved by engaging in a vertical integration with Econet; a well-established telecommunications company behind Africa's mobile banking system. This would have been a more radical approach with the potential to put DHL back on the front foot in its wrestle to gain competitive advantage from the local competitors and milk imports from SA.

Theory: Shepherd and Patzelt (2017). Trailblazing in entrepreneurship: Creating new paths for understanding the field.

(9) Did Antony demonstrate an entrepreneurial touch at DHL? Either you agree or disagree, highlight the decisions he made or should have made to demonstrate entrepreneurship.

\section{Answer:}

For a start, Antony has an MBA. Some students would explain that he may have been using some of the knowledge he acquired from such a high-level course in the decisions he made at DHL. Clearly, his focus on developing human capital is certainly a hint that he showed an entrepreneurial touch. Also, inviting suggestions for improvements at DHL was another sign of entrepreneurial touch. Other students may point to Antony insistence that DHL were not going to change course even if their "restructure, expand and diversify" strategy only achieved inconsistent commercial results. This is a sign of a lack of strategic options and yet in entrepreneurial organisations its leaders have to have contingency plans to fall back on. Also, the decisions taken at DHL were very much reactive rather proactive, risky but calculated and lack vision. Yet, these attributes are essential for better performance in rapidly changing markets such as the dairy sector in Zimbabwe.

Theory: Burns (2012) on Corporate entrepreneurship: innovation and strategy in large organizations. 


\section{Case Summary}

Dairibord Holdings Limited is one of the largest milk and milk beverages producing companies in Zimbabwe and the southern African region. Established in 1953 as a state-owned-enterprise (SOE) under the name DMB, it was the only organisation that received all milk supplied by registered producers which it then processed and distributed to consumers at prescribed prices (Reserve Bank of Zimbabwe (RBZ), 2007). When it was privatised in 1994, DMB had all the characteristics of an inefficiently managed SOE. Following its privatisation DMB was subsequently registered as Dairibord Zimbabwe Limited under the Companies’ Act of 1994. Leading up to 1997 the company operated as a profitable enterprise.

Problems started to emerge early 2000. The general economy in Zimbabwe started to deteriorate. In Malawi where DHL had a 40\% stake in DML, a devalued kwacha meant reduced revenues. Also, a depreciating Rand in SA made importing milk and milk beverages into Zimbabwe cheaper. Clearly, imported milk and milk beverages from SA provided a significant threat to DHL's market dominance. With cash-strapped consumers whose buying behaviour was inclined to favour cheaper options from SA than expensive DHL dairy products.

The ill-conceived 2008 indigenisation policy (FT, 2013; Marazanye, 2016) initiated by the government made small-scale farmers able to compete directly with DHL. Furthermore, driving away experienced and well-established farmers during, fresh 2009, uncoordinated farm invasion disrupted the flow of milk into Dairibord, hence the reduced milk volumes recorded between 2012 and 2017. Natural causes such the drought in the 90s the partial drought of 2015 contributed to DHL's competitive mix. Clearly, DHL was constantly on the back foot. 
Its dominant strategy was very much modelled by Antony and his top management team around a "restructure, expand and diversify" approach. This approach was repeatedly recycled at DHL. Specifically, new production facilities in Chitungwiza -a town on the outskirts of the capital city Harare were commissioned to produce and process a new traditional favourite Pfuko yeMaheu, and a sterilised milk facility in Chipinge -a city to the south east of the Zimbabwe was also opened. While this was happening, some facilities were streamlined e.g. in Gweru factories closures were designed to enhance operational efficiency.

Little time was wasted in offloading less performing services. E.g. a 40\% stake in M. E. Charhons to Cairns Holdings offloaded in 2012 and Mulanje Peak Foods was sold in the same year. Also, some operations were relocated from Mutare and Bulawayo the capital city - Harare and a nearby town of Chitungwiza. Nonetheless, the strategy never quite worked.

DHL's management approaches described in the case provides some insight into the issues associated with entrepreneurial decision-making in businesses, especially those businesses that operate in rapidly changing market conditions such as Zimbabwe's dairy market. Instead of carefully assessing projected market conditions and consider adjusting DHL's business model to withstand market volatility, Antony and his management team were steadfast on a strategy that was probably less-effective. All it ever-achieved were inconsistent revenues and declining profit margins. Why the company did not consider other strategic options to substitute their tried and tested "restructure, expand and diversify" strategy is puzzling. In that respect, the case provides students with the opportunity to debate and discuss entrepreneurship and leadership concepts that are associated with business performance improvement through carefully considering strategic issues, business planning and external market conditions. 


\section{Audience}

The case is suitable for business management courses including: MSc entrepreneurship and undergraduate entrepreneurship programs, business management \& innovation and strategic management. It gives, both postgraduate and undergraduate, students a chance to explore entrepreneurial leadership, management and decision making in rapidly changing market conditions. So, the DHL case is recommended for use at either undergraduate or postgraduate level.

\section{Topics that can be covered:}

1. Entrepreneurial leadership

- Entrepreneurial mind set

- Business management

- Business development

- External market analysis

- Strategic formulation

- Strategic options

- Entrepreneurial decision making

- Opportunity assessment decisions

2. Strategic entrepreneurship

- Strategic "fit"

- Venturing and Opportunity-led entrepreneurship

- Investing

- Changing

- Strategy renewal

- Adaptation

- Business re-alignment

3. Transient markets and business planning

- The nature of the dairy market in Zimbabwe

- Types of challenges in the dairy market

- Political, and socio-economic factors

- Intensive local and foreign competition

- Strategic alliances

- Building networks 
The case study was tested in an MSc Enterprise Context module and an undergraduate final year group studying Contemporary Issues in Strategy and Entrepreneurship. Its relevance to postgraduate and entrepreneurship students was noticeable in the way it stimulated and encouraged debate on entrepreneurial decision making when operating in challenging business conditions. The need to understand the enterprise context (dairy industry in Zimbabwe) and to consider the most appropriate entrepreneurial approach in terms of entrepreneurship and leadership. Students were presented with the case a week before a session for 120 minutes on entrepreneurial leadership in rapidly changing markets.

\section{Pedagogy}

In terms of pedagogy, this case can be used to achieve the following:

- an understanding of the challenges associated with operating in rapidly changing market conditions

- an awareness of the importance of developing strategic options in businesses

- an appreciation of the importance of effective strategy formation in intensively competitive business sectors

- to explore alternative entrepreneurial approaches to business that face intractable challenges

- to appreciate the role of management in undertaking analyzing rapidly changing markets

\section{Methodological justification}

The case study was produce from secondary data publicly available information on DHL. Specifically, secondary analysis (Bryman, 2008) was deemed appropriate because it provided the researcher with quality archived and publicly available information concerning DHL's management and business activities. This approach was selected ahead of structured interviews and self-administered questionnaires that are extremely time consuming and expensive to conduct (Gray, 2018). An important reason for using secondary analysis in producing DHL's case was the ability to reanalyze DHL's management and business activities offering students an opportunity to provide their own interpretations (Bryman and Bell, 2015). 


\section{Reference:}

Bryman, A., and Bell, E. (2015). Business research methods. Oxford University Press, USA. ISBN: 978-0-19-925938-0.

Bryman, A., (2008). Social Research Methods, $3^{\text {rd }}$ Edition, Oxford University Press, USA. ISBN: 978-0019-920295-9

De Wit B, Meyer R (2014). Strategy: An International Perspective, 5th Edition, Cengage Learning, EMEA.

FT, (2013). Zimbabwe's indigenisation policy: falling apart? Available at: https://www.ft.com/content/08b85cf2-e77c-3fee-9d32-9af8e6e5a790, Accessed on 22.12.2017.

Gray, D. E., (2018). Doing Research in the Real World, $4^{\text {th }}$ Edition, SAGE Publications, Thousand Oaks: California. ISBN: 978-1-4739-4726-9.

Hamel, G, and Prahalad, C. K., (1989). To revitalize corporate performance, we need a whole new model of strategy. Harvard Business Review, 67(3), pp.63.

Kuratko DF (2014). Entrepreneurship: Theory, Process, Practice, $9^{\text {th }}$ Edition, Cengage/South-western Publishers.

Marazanye, K., (2016). An Analysis of Indigenisation and Economic Empowerment in Zimbabwe, Thesis presented in partial fulfilment of the requirements for the degree Masters in Public Administration in the Faculty of Economic and Management Science at Stellenbosch University. Stellenbosch University Library, Available at: https://scholar.sun.ac.za/handle/10019.1/100093, Accessed on 20.12.2017.

RBZ, (2007). Unlocking value through privatisation of targeted public enterprises, Supplement to the January 2007 Monetary Policy Review, Available at: http://www.rbz.co.zw/assets/public-enterprises.pdf, Accessed on 28.12.2017

Slack, N. and Lewis, M., (2008). Operations strategy. $2^{\text {nd }}$ Edition, John Wiley and Sons, Ltd. Prentice Hall: Financial Times, Essex, ISBN: 978-0-273-69519-6

Simba, A., Smith, D. and Dube, T., (2018). Competing with the Grey Market: Puzey and Payne in Zimbabwe, The CASE Journal 14(2) (In Press, Print Published: 05-Mar-2018).

Simba, A., and Nyandoro, Z., (2016). Strategic management in retail pharmacy: The case of Zimbabwean companies, African Journal of Business Management, 10(9), pp. 233-244. ISSN 1993-8233. DOI: 10.5897/AJBM2016.8010.

Timmons, J. A., (1978). "Characteristics and role demand of entrepreneurship", American Journal of Small Business 3(1), pp. 5-17.

\section{Reading suggested as support for theory}

Burns, P., (2012). Corporate entrepreneurship: innovation and strategy in large organizations. Palgrave Macmillan.

Coglister, C and Brigham, K., (2004). "The intersection of leadership and entrepreneurship: Mutual lessons learned," The Leadership Quarterly 15(6) pp. 771-799.

Covin, J. G., and Slevin, D. (2002). "The Entrepreneurial Imperatives of Strategic Leadership," in Strategic Entrepreneurship: Creating a New Mind-set. Eds. M. A. Hitt, R. D. Ireland, S. M. Camp and D. L. Sexton. Oxford: Blackwell Publishers, 309-327.

Duncan, R. B., (1972). "Characteristics of organisational environment and perceived environmental uncertainty", Administrative Science Quarterly 17(1972), pp.313-327.

Hitt, M. A., Ireland, R. D., Sirmon, D. G., \& Trahms, C. A. (2011). Strategic entrepreneurship: creating value for individuals, organizations, and society. The Academy of Management Perspectives, 25(2), 57-75. 
Hitt, M. A., Ireland, R. D., Camp, S. M., and Sexton, D. L. (2001). Strategic entrepreneurship: Entrepreneurial strategies for wealth creation. Strategic management journal, 22(6-7), 479491.

Kuratko, D.F., (2017). Entrepreneurship: Theory, Process, and Practice. Cengage Learning, Boston: USA.

Kuratko, D. F., \& Audretsch, D. B. (2009). Strategic entrepreneurship: exploring different perspectives of an emerging concept. Entrepreneurship Theory and Practice, 33(1), 1-17.

Ireland, R. D., Hitt, M. A. and Sirmon, D. G., (2003). "A Model of Strategic Entrepreneurship: The Construct and Its Dimensions", Journal of Management Development 29(6), pp. 963-989.

Ireland, R. D., Covin, J. G., and Kuratko, D. F., (2009). "Conceptualizing corporate entrepreneurship strategy", Entrepreneurship theory and practice 33(1), 19-46.

Shepherd, D. A., and Patzelt, H. (2017). Trailblazing in entrepreneurship: Creating new paths for understanding the field. Palgrave Macmillan imprint published by Springer, ISBN: 978-3319-48700-7. 